\title{
Marinomonas pontica sp. nov., isolated from the Black Sea
}

Correspondence

Elena P. Ivanova

eivanova@swin.edu.au
Elena P. Ivanova, ${ }^{1}$ Olga M. Onyshchenko, ${ }^{2}$ Richard Christen, ${ }^{3}$ Anatoly M. Lysenko, ${ }^{4}$ Natalia V. Zhukova, ${ }^{5}$ Ludmila S. Shevchenko ${ }^{6}$ and Elena A. Kiprianova ${ }^{2}$

\author{
${ }^{1}$ Industrial Research Institute, Swinburne University of Technology, PO Box 218, Hawthorn, \\ Victoria 3122, Australia \\ ${ }^{2}$ Institute of Microbiology and Virology, Ukraine Academy of Sciences, Ukraine \\ 3UMR6543 CNRS - Université de Nice Sophia Antipolis, Centre de Biochimie, Parc Valrose, \\ F06108 Nice Cedex 2, France \\ ${ }^{4}$ Institute of Microbiology of the Russian Academy of Sciences, 117811 Moscow, Russian \\ Federation \\ ${ }^{5}$ Institute of Marine Biology of the Far-Eastern Branch of the Russian Academy of Sciences, \\ 690041, Palchevskogo Street 17, Vladivostok, Russian Federation \\ ${ }^{6}$ Pacific Institute of Bioorganic Chemistry of the Far-Eastern Branch of the Russian Academy \\ of Sciences, 690022 Vladivostok, Pr. 100 Let Vladivostoku 159, Russian Federation
}

A Gram-negative, polarly flagellated bacterium was isolated from a sea-water sample collected from the Karadag Natural Reserve of the Eastern Crimea and characterized to clarify its taxonomic position. 16S rRNA gene sequence-based phylogenetic analysis of this novel organism revealed Marinomonas vaga, Marinomonas communis, Marinomonas mediterranea, Marinomonas primoryensis and 'Marinomonas protea' as its closest relatives (similarity 95-97 \%). The $\mathrm{G}+\mathrm{C}$ content of the DNA was $46.5 \mathrm{~mol} \%$. The organism grew between 4 and $33^{\circ} \mathrm{C}$, tolerated $10 \% \mathrm{NaCl}$, was slightly alkaliphilic and was not able to degrade starch, gelatin, agar or Tween 80 . Phosphatidylethanolamine $(53.4 \%)$ and phosphatidylglycerol $(46.6 \%)$ were the predominant phospholipids. The major fatty acids were $16: 0(15 \cdot 5 \%), 16: 1 \omega 7(26 \cdot 7 \%)$ and $18: 1 \omega 7$ $(47 \cdot 1 \%)$. The phylogenetic, genetic and physiological properties of the organism placed it within a novel species, proposed as Marinomonas pontica sp. nov., the type strain of which is $46-16^{\top}$

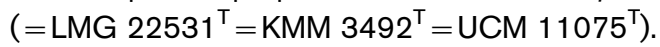

The genus Marinomonas van Landschoot and De Ley 1984 was created to accommodate two misclassified Alteromonas species, Marinomonas communis and Marinomonas vaga (van Landschoot \& De Ley, 1983; Baumann et al., 1984; Gauthier \& Breittmayer, 1992). More recently, two additional species, Marinomonas mediterranea and Marinomonas primoryensis, have been described (Solano \& Sanchez-Amat, 1999; Romanenko et al., 2003).

In this study, we report on the characterization of a novel mesophilic bacterium of the genus Marinomonas isolated from sea-water samples collected in the Karadag Natural Reserve of the Eastern Crimea. This work was part of a

Published online ahead of print on 20 August 2004 as DOI 10.1099/ ijs.0.63326-0.

The GenBank/EMBL/DDBJ accession number for the 16S rRNA gene sequence of strain $46-16^{\top}$ is $A Y 539835$. taxonomic survey of free-living microbial populations of the Black Sea. During the course of this work, 51 Alteromonas-like strains of different phenotypes were isolated. The phenotype of the majority of the strains closely resembled Pseudoalteromonas, while a few had distinct phenotypes. Further detailed taxonomic investigation of one such strain, $46-16^{\mathrm{T}}$, revealed a number of particular phenotypic traits, e.g. lack of amylase, gelatinase, lipase and chitinase, and utilization of glycerol, lactate and some other carbon sources, which led us to assume that this strain belonged to the genus Marinomonas. Genetic and phylogenetic analyses confirmed this conclusion and allowed us to conclude that this organism constitutes a novel species, for which we propose the name Marinomonas pontica sp. nov.

Water samples were collected in July 2000 from a depth of 1-3 m (salinity $17 \%$, temperature $16^{\circ} \mathrm{C}$ ) using a standard hydrological plastic bathometer in the Karadag Natural Reserve (a central part of the Black Sea coast line). Samples 
were kept at $4{ }^{\circ} \mathrm{C}$ and processed within $4-8 \mathrm{~h}$. A portion of sea water $(0 \cdot 1 \mathrm{ml})$ was plated on to marine agar 2216 (Difco) or medium B containing $0 \cdot 2 \%(\mathrm{w} / \mathrm{v})$ Bacto peptone (Difco), $0 \cdot 2 \%(\mathrm{w} / \mathrm{v})$ casein hydrolysate (Merck), $0 \cdot 2 \%$ $(\mathrm{w} / \mathrm{v})$ Bacto yeast extract (Difco), $0 \cdot 1 \%(\mathrm{w} / \mathrm{v})$ glucose, $0.02 \%(\mathrm{w} / \mathrm{v}) \mathrm{KH}_{2} \mathrm{PO}_{4}, 0 \cdot 005 \%(\mathrm{w} / \mathrm{v}) \mathrm{MgSO}_{4} .7 \mathrm{H}_{2} \mathrm{O}, 0 \cdot 5 \%$ $(\mathrm{w} / \mathrm{v})$ Bacto agar (Difco), $50 \%(\mathrm{v} / \mathrm{v})$ natural sea water and $50 \%(\mathrm{v} / \mathrm{v})$ distilled water at $\mathrm{pH} 7 \cdot 8$. Plates were incubated aerobically at room temperature $\left(\sim 22-25^{\circ} \mathrm{C}\right)$ for 5,7 or 10 days. The isolation and purification of bacterial strains was done as described elsewhere (Ivanova et al., 1996). Strains were stored at $-80^{\circ} \mathrm{C}$ in marine 2216 broth (Difco) supplemented with $20 \%(\mathrm{v} / \mathrm{v})$ glycerol.

Unless otherwise indicated, phenotypic characteristics were studied using standard procedures (Baumann et al., 1972; Smibert \& Krieg, 1994) as described previously (Ivanova et al., 1996, 1998). The following physiological and biochemical properties were examined: oxidation/fermentation of glucose, denitrification, catalase and oxidase activities, gelatin liquefaction, arginine dihydrolase, lysine decarboxylase, ornithine decarboxylase, and the ability to hydrolyse starch, gelatin, chitin and Tween 80 . Growth rate was studied under optimal physiological conditions and the requirement for $\mathrm{Na}^{+}$ions was studied on medium containing (w/v) $0.25 \%$ yeast extract, $0.1 \%$ glucose, $0.02 \% \quad \mathrm{~K}_{2} \mathrm{HPO}_{4}$ and $0.005 \% \quad \mathrm{MgSO}_{4} .7 \mathrm{H}_{2} \mathrm{O} \quad(\mathrm{pH} 7 \cdot 8$ ). Salt-tolerance tests were performed on trypticase soy agar (TSA; Difco) with $\mathrm{NaCl}$ concentrations of $0 \cdot 6-20 \cdot 0 \%(\mathrm{w} / \mathrm{v})$. Cellular morphology was examined by phase-contrast light microscopy of $24 \mathrm{~h}$ cultures grown on agar plates. Electron micrographs of negatively stained cells were prepared using a Zeiss EM 10 CA electron microscope $(80 \mathrm{kV})$. A drop of particle-free (autoclaved and ultracentrifuged) distilled water was placed on the bacterial growth (a few colonies) of a $24 \mathrm{~h}$ culture grown on agar plates. The sample (30 $\mu \mathrm{l})$ of resulting bacterial suspension was applied to carbon- and Formvar-coated 400-mesh copper grids, a drop of $1.25 \%$ uranyl acetate was added and the bacteria were allowed to adhere for $1 \mathrm{~min}$ at room temperature. Superfluous liquid was gently removed using a piece of filter paper.

Susceptibility to antibiotics was tested by the routine diffusion-plate method, employing medium $B$ agar and discs impregnated with the following antibiotics: benzylpenicillin $(10 \mu \mathrm{g})$, lincomycin $(15 \mu \mathrm{g})$, oleandomycin $(10 \mu \mathrm{g})$, polymyxin $(25 \mu \mathrm{g})$, streptomycin $(30 \mu \mathrm{g})$, erythromycin $(20 \mu \mathrm{g})$, tetracycline $(10 \mu \mathrm{g})$, cephalosporin $(30 \mu \mathrm{g})$, furadonin $(10 \mu \mathrm{g})$, nalidixic acid $(10 \mu \mathrm{g})$ and ciprofloxacin $(15 \mu \mathrm{g})$. Antibacterial activity was determined by the agardiffusion assay, based on the method described by Barry (1980). Cultures $(0 \cdot 1 \mathrm{ml})$ of indicator test strains were spread on TSA plates in which circular wells $(8 \mathrm{~mm}$ diameter) had been cut. Samples $(0 \cdot 1 \mathrm{ml})$ of the supernatant were tested and areas of inhibited bacterial growth were measured after incubation for $48 \mathrm{~h}$ at $28^{\circ} \mathrm{C}$. Zones of inhibited growth of the indicator strains surrounding the wells were observed. Antimicrobial activities were tested against Staphylococcus aureus ATCC 6538P, Bacillus subtilis ATCC 6633, Escherichia coli ATCC 25922, Pseudomonas aeruginosa ATCC 27853, Candida albicans ATCC 885-653, the phytopathogenic fungi Penicillium chrysogenum UCM F-57672 and Cochliobolus sativus UCM F-11224 and the cyanobacteria Synechocystis minuscula UCM A-14 and Synechococcus cedrorum UCM A-15. The culture fluid of strain $46-16^{\mathrm{T}}$ grown in marine broth 2216 for $24 \mathrm{~h}$ inhibited the growth of $C$. sativus, while its cellular extract was active against Synechocystis minuscula. The results of the examination of the other morphological and physiological properties are shown in Table 1 and given in the species description.

For analysis of phospholipids and fatty acids, strains were grown at $28^{\circ} \mathrm{C}$ on marine agar 2216. After 48 h growth, cells were harvested. Lipids were extracted by a method modified from Bligh \& Dyer (1959). Polar lipids were separated by two-dimensional micro-TLC in solvent systems described by Vaskovsky \& Terekhova (1979). Lipids were detected by TLC using $10 \% \mathrm{H}_{2} \mathrm{SO}_{4}$ in methanol with subsequent heating to $180^{\circ} \mathrm{C}$ and using specific reagents for phospholipids (Vaskovsky et al., 1975) and amino-containing lipids ( $2 \%$ ninhydrin in acetone) and Dragendorf's reagent for choline lipids. Phospholipids were quantified by the method of Vaskovsky et al. (1975). Lipids were treated with $5 \%$ $\mathrm{HCl}$ in methanol at $80^{\circ} \mathrm{C}$ for $180 \mathrm{~min}$ to produce fatty acid methyl esters (FAMEs) (Christie, 1982). FAMEs were analysed by flame ionization detection GC (Shimadzu GC-17) with a fused silica capillary column (30 $\mathrm{m} \times$ $0 \cdot 25 \mathrm{~mm}$ ) coated with Supelcowax 10 at $210^{\circ} \mathrm{C}$. Helium was used as a carrier gas. FAMEs were identified by comparing the retention times with those of authentic standards and using equivalent chain length (ECL) measurements. To ensure correct identification, FAMEs were analysed by GC-MS using a model GCMS-QP5050A (Shimadzu) fitted with an MDN-5S capillary column $(30 \mathrm{~m} \times 0.25 \mathrm{~mm})$. The column temperature was programmed as follows: $1 \mathrm{~min}$ at $170{ }^{\circ} \mathrm{C}$, followed by an increase to $240{ }^{\circ} \mathrm{C}$ at a rate of $2{ }^{\circ} \mathrm{C} \mathrm{m^{-1 }}$, and held at $240^{\circ}$ for $20 \mathrm{~min}$. The temperature of the injector and detector was $250{ }^{\circ} \mathrm{C}$. Phosphatidylethanolamine and phosphatidylglycerol were the major constituents of the phospholipids, accounting for $53 \cdot 4 \pm 0 \cdot 7$ and $46 \cdot 6 \pm 0 \cdot 7 \%$ of the total phospholipids, respectively. The cellular fatty acids comprised 14:0 (1.6\%), 15:0-ai

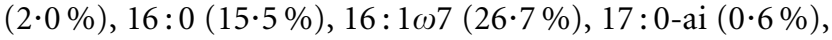
$18: 0(5 \cdot 7 \%), 18: 1 \omega 7(47 \cdot 1 \%)$ and $19: 0$-ai $(0 \cdot 8 \%)$, with the most diagnostic cis-hexadecenoic $(16: 1 \omega 7)$ and cisoctadecenoic $(18: 1 \omega 7)$ and hexadecanoic $(16: 0)$ fatty acids. Overall, the phospholipid and fatty acid patterns of the novel isolate possessed a profile characteristic of the genus Marinomonas (Ivanova et al., 2000).

DNA was extracted from cells grown overnight on medium B following the method of Marmur (1961). The G+C content of the DNA was determined as described by Marmur \& Doty (1962) and was 46.5 $\pm 0 \cdot 4 \mathrm{~mol} \%$.

The 16S rRNA gene for strain $46-16^{\mathrm{T}}$ was amplified and 
Table 1. Characteristics that differentiate $M$. pontica sp. nov. from phylogenetically related species

Taxa: 1, M. pontica sp. nov.; 2, M. vaga; 3, M. communis; 4, M. mediterranea; 5, M. primoryensis. Data from this study, Baumann et al. (1972), Solano et al. (1997), Solano \& Sanchez-Amat (1999) and Romanenko et al. (2003). All strains were Gram-negative, motile, rod-shaped organisms, negative for amylase production, arginine dihydrolase and L-tyrosine utilization. All utilized citrate and acetate. $\mathrm{V}$, Variable reaction depending on the strain; ND, data not available.

\begin{tabular}{|c|c|c|c|c|c|}
\hline Characteristic & 1 & 2 & 3 & 4 & 5 \\
\hline $\mathrm{G}+\mathrm{C}$ content $(\mathrm{mol} \%)$ & 46 & $47-49$ & $46-48$ & 46 & 45 \\
\hline Flagellation & Subpolar/polar & Polar & Polar & Polar & Polar \\
\hline Pigment & None & None & None & Melanin-like & Yellowish \\
\hline Oxidase & + & - & + & - & + \\
\hline \multicolumn{6}{|l|}{ Growth at: } \\
\hline $4^{\circ} \mathrm{C}$ & + & - & - & - & + \\
\hline $35^{\circ} \mathrm{C}$ & - & + & + & - & - \\
\hline $40^{\circ} \mathrm{C}$ & - & - & + & - & - \\
\hline Growth on $8 \% \mathrm{NaCl}$ & + & + & + & - & - \\
\hline \multicolumn{6}{|l|}{ Production of: } \\
\hline Lipase & - & - & - & + & - \\
\hline Gelatinase & - & - & - & + & - \\
\hline \multicolumn{6}{|l|}{ Utilization of: } \\
\hline D-Glucose & + & + & + & + & $\mathrm{V}$ \\
\hline Maltose & + & $\mathrm{V}$ & $\mathrm{V}$ & - & + \\
\hline$m$-Hydroxybenzoate & + & + & + & - & + \\
\hline Malate & + & + & + & + & $\mathrm{V}$ \\
\hline L-Arginine & + & V & - & ND & $\mathrm{V}$ \\
\hline L-Lysine & + & $\mathrm{V}$ & - & $\mathrm{ND}$ & + \\
\hline
\end{tabular}

sequenced as described elsewhere (Ivanova et al., 2001, 2003a, b). Phylogenetic analyses were done as described previously (Ivanova et al., 2004) and as described in detail at http://bioinfo.unice.fr. Briefly, a BLAST query allowed us to retrieve the 100 most similar sequences from the EMBL public database. These sequences were aligned and alignments were checked manually. Phylogenetic trees were constructed using three different methods: bio-neighbour joining, maximum likelihood and maximum parsimony. For the neighbour-joining analysis, distance matrices were calculated using the Kimura two-parameter correction and the analysis was performed according to Gascuel (1997). Maximum likelihood (using the global option) and maximum parsimony were from PHYLIP (Felsenstein, 1993). Phylogenetic trees were drawn using NJPLOT (Berry \& Gascuel, 1996). For the final tree, only closely related sequences (as deduced from the global phylogenetic analyses) from cultured strains and, where possible, from type strains were retained.

According to the phylogenetic analyses, strain $46-16^{\mathrm{T}}$ formed a cluster with unidentified marine bacterium Tw-9 but not with other species with validly published names of the genus Marinomonas. The 16S rRNA gene sequences shared $95-97 \%$ identity with genes from M. primoryensis, M. vaga, M. communis, M. mediterranea and two unpublished species, 'Marinomonas protea' and 'Marinomonas alkaliphila' (Fig. 1). Since bacteria that differ by more than $2.5 \%$ at the $16 \mathrm{~S}$ rRNA gene sequence level are unlikely to exhibit more than $60-70 \%$ DNA-DNA hybridization values (Wayne et al., 1987; Stackebrandt \& Goebel, 1994; Rosselló-Mora \& Amann, 2001; Keswani \& Whitman, 2001), it could be inferred that the new strain from sea water represented a novel species.

The novel isolate $46-16^{\mathrm{T}}$ could be clearly distinguished from other species of the genus Marinomonas by the combination of the following features: salinity tolerance and temperature for growth; ability to hydrolyse starch, gelatin and casein; susceptibility to certain antibiotics; and carbon source utilization. In particular, strain $46-16^{\mathrm{T}}$ differed from $M$. primoryensis by the ability to grow above $30{ }^{\circ} \mathrm{C}$, tolerance to concentrations of $\mathrm{NaCl}$ greater than $6 \%$ and the ability to utilize glycerol; from $M$. mediterranea by the lack of pigments, the positive oxidase reaction, the inability to reduce nitrate and produce lipase and gelatinase, and the ability to utilize glycerol; and from $M$. vaga and M. communis by the growth temperature range, oxidase reaction, non-susceptibility to benzylpenicillin and some carbon compounds utilization (Table 1). Consequently, we propose that strain $46-16^{\mathrm{T}}$ isolated from the Black Sea be classified as a novel species, Marinomonas pontica sp. nov. 


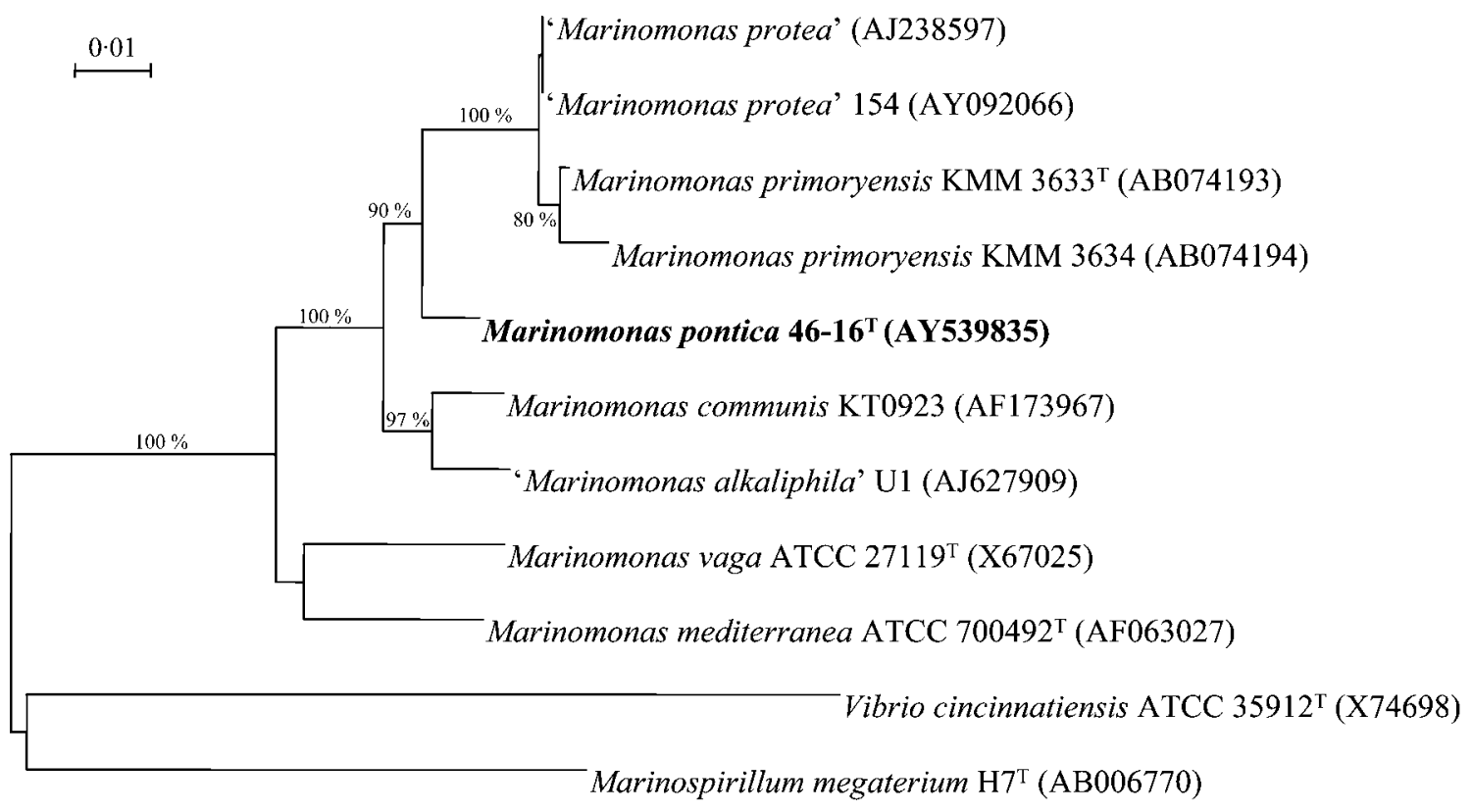

Fig. 1. Phylogenetic position of M. pontica sp. nov. according to $16 \mathrm{~S}$ rRNA gene sequence analysis. An unrooted tree is shown resulting from neighbour-joining analysis. Percentages of bootstrap analysis (1000 replications) are indicated only for branches also retrieved by maximum parsimony and maximum likelihood.

\section{Description of Marinomonas pontica sp. nov.}

Marinomonas pontica (pon.ti'ca. L. fem. adj. pontica related to the Black Sea, of the Black Sea).

Cells are rod shaped, $0 \cdot 8-1 \cdot 6 \mu \mathrm{m}$ in length and $0 \cdot 4-0 \cdot 6 \mu \mathrm{m}$ in diameter (by electron microscopy), motile with a single subpolar flagellum and Gram-negative. Aerobic and chemoheterotrophic. They do not form endospores. Colonies on marine agar 2216 are slightly creamy, circular, smooth and convex with an entire edge. Organic growth factors are not required. The organism requires $\mathrm{Na}^{+}$ions and grows on $0 \cdot 5-10 \% \mathrm{NaCl}$. No growth is detected on $15 \% \mathrm{NaCl}$. The temperature growth range is $4-33^{\circ} \mathrm{C}$, with optimum growth occurring at $20-25^{\circ} \mathrm{C}$ and no growth detected at $40{ }^{\circ} \mathrm{C}$. The $\mathrm{pH}$ for growth ranges from $6 \cdot 0$ to $10 \cdot 0$, with the optimum at $\mathrm{pH} 7 \cdot 5-8 \cdot 5$. Oxidase- and catalase-positive. Does not reduce nitrate to nitrite. Arginine dihydrolase and lysine decarboxylase are not exhibited. Does not produce amylase, esterase (Tween 80), proteinase (gelatinase) or agarase. Chitin is not hydrolysed. D-Glucose is utilized as a sole source of carbon. The following substrates are utilized: $\alpha$-D-glucose, sucrose, D-trehalose, cellobiose, $\alpha$-D-lactose, maltose, D-ribose, L-rhamnose, D-fructose, glycogen, dextrin, acetate, formate, butyrate, propionate, malate, lactate, citrate, pyruvate, ethanol, fumarate, D-mannitol, $m$-hydroxybenzoate, betaine, D-alanine, L-alanine, Lglycine, sarcosine, sodium succinate, L-proline, Lglutamate, L-asparagine, L-serine, L-ornithine, L-arginine, L-lysine, L-histidine and L-phenylalanine. Does not utilize D-xylose, L-arabinose, D-arabinose, D-mannose, D-sorbitol,
D-galactose, D-raffinose, valerate, glycerol, adonitol, $m$-inositol, benzoate, $o$-hydroxybenzoate, phenylacetate, fumarate, Tween 80 , leucine, L-threonine L-cysteine, methionine, L-phenylalanine or L-tyrosine. Non-susceptible to benzylpenicillin; susceptible to lincomycin, oleandomycin, polymyxin, streptomycin, erythromycin, tetracycline, cephalosporin, furadonin, nalidixic acid and ciprofloxacin. Phosphatidylethanolamine and phosphatidylglycerol are the predominant phospholipids. Major cellular fatty acids are cis-hexadecenoic $(16: 1 \omega 7)$, cis-octadecenoic $(18: 1 \omega 7)$ and hexadecanoic $(16: 0)(\sim 89 \%)$.

The type strain is $46-16^{\mathrm{T}} \quad\left(=\mathrm{LMG} \quad 22531^{\mathrm{T}}=\mathrm{KMM}\right.$ $\left.3492^{\mathrm{T}}=\mathrm{UCM} 11075^{\mathrm{T}}\right)$. The $\mathrm{G}+\mathrm{C}$ content of its DNA is $46.5 \mathrm{~mol} \%$. Isolated from a sea-water sample collected in the Karadag Natural Reserve of the Eastern Crimea, the Black Sea.

\section{Acknowledgements}

This study was partially supported by funds from the Australian Research Council (ARC), grant no. 2-2.16 from the Federal Agency for Science of the Ministry of Education and Science of the Russian Federation, grant 02-04-49517 from the Russian Foundation for Basic Research and grant 03-1-0-05-005 from the Far-Eastern Branch of the Russian Academy of Sciences. This work was also supported by funds from the European Commission for the AQUA-CHIP project (QLK4-2000-00764). The authors are solely responsible for the content of this publication. It does not represent the opinion of the European Commission. The European Commission is not responsible for any use that might be made of data appearing herein. 


\section{References}

Barry, A. I. (1980). Procedures and theoretical considerations for testing antimicrobial agents in agar media. In Antibiotics in Laboratory Medicine, pp. 10-16. Edited by V. Logan. Baltimore: William \& Wilkins.

Baumann, L., Baumann, P., Mandel, M. \& Allen, R. D. (1972). Taxonomy of aerobic marine eubacteria. J Bacteriol 3, 402-429.

Baumann, P., Gauthier, M. J. \& Baumann, L. (1984). Genus Alteromonas Baumann, Baumann, Mandel and Allen 1972, $418^{A L}$. In Bergey's Manual of Systematic Bacteriology, vol. 1, pp. 343-352. Edited by N. R. Krieg \& J. G. Holt. Baltimore: Williams \& Wilkins.

Berry, V. \& Gascuel, O. (1996). Interpretation of bootstrap trees: threshold of clade selection and induced gain. Mol Biol Evol 13, 999-1011.

Bligh, E. G. \& Dyer, W. J. (1959). A rapid method of lipid extraction and purification. Can J Biochem Physiol 7, 911-915.

Christie, W. W. (1982). Lipid Analysis: Isolation, Separation, Identification and Structural Analysis of Lipids. Oxford: Pergamon Press.

Felsenstein, J. (1993). PHYLIP: Phylogeny Inference Package, version 3.5c. Department of Genetics, University of Washington, Seattle, WA, USA.

Gascuel, O. (1997). BIONJ: an improved version of the NJ algorithm based on a simple model of sequence data. Mol Biol Evol 14, 685-695.

Gauthier, M. J. \& Breittmayer, V. A. (1992). The genera Alteromonas and Marinomonas. In The Prokaryotes. A Handbook on the Biology of Bacteria: Ecophysiology, Isolation, Identification, Applications, vol. 3, pp. 3046-3070. Edited by A. Balows, H. G. Trüper, M. Dworkin, H. Harber, \& K.-H. Schleifer. Berlin: Springer.

Ivanova, E. P., Kiprianova, E. A., Mikhailov, V. V., Levanova, F. G., Garagulya, A. G., Gorshkova, N. M., Yumoto, N. \& Yoshikawa, S. (1996). Characterization and identification of marine Alteromonas nigrifaciens strains and emendation of the description. Int J Syst Bacteriol 46, 223-228.

Ivanova, E. P., Kiprianova, E. A., Mikhailov, V. V. \& 7 other authors (1998). Phenotypic diversity of Pseudoalteromonas citrea from different marine habitats and emendation of the description. Int J Syst Bacteriol 48, 247-256.

Ivanova, E. P., Zhukova, N. V., Svetashev, V. I., Gorshkova, N. M., Kurilenko, V. V., Frolova, G. M. \& Mikhailov, V. V. (2000). Evaluation of phospholipid and fatty acid compositions as chemotaxonomic markers of Alteromonas-like proteobacteria. Curr Microbiol 41, 341-345.

Ivanova, E. P., Sawabe, T., Gorshkova, N. M., Svetashev, V. I., Mikhailov, V. V., Nicolau, D. V. \& Christen, R. (2001). Shewanella japonica sp. nov. Int J Syst Evol Microbiol 51, 1027-1033.

Ivanova, E. P., Nedashkovskaya, O. I., Zhukova, N. V., Nicolau, D. V., Christen, R. \& Mikhailov, V. V. (2003a). Shewanella waksmanii sp. nov., isolated from a sipuncula (Phascolosoma japonicum). Int J Syst Evol Microbiol 53, 1471-1477.

Ivanova, E. P., Sawabe, T., Zhukova, N. V. \& 8 other authors (2003b). Occurrence and diversity of mesophilic Shewanella strains isolated from the North-West Pacific Ocean. Syst Appl Microbiol 26, 293-301.

Ivanova, E. P., Gorshkova, N. M., Sawabe, T. \& 8 other authors (2004). Sulfitobacter delicatus sp. nov. and Sulfitobacter dubius sp. nov., respectively, from a starfish (Stellaster equestris) and sea grass (Zostera marina). Int J Syst Evol Microbiol 54, 475-480.

Keswani, J. \& Whitman, W. B. (2001). Relationship of $16 \mathrm{~S}$ rRNA sequence similarity to DNA hybridization in prokaryotes. Int J Syst Evol Microbiol 51, 667-678.

Marmur, J. (1961). A procedure for the isolation of deoxyribonucleic acid from microorganisms. J Mol Biol 3, 208-218.

Marmur, J. \& Doty, P. (1962). Determination of the base composition of deoxyribonucleic acid from its thermal denaturation temperature. J Mol Biol 5, 109-118.

Romanenko, L. A., Uchino, M., Mikhailov, V. V., Zhukova, N. V. \& Uchimura, T. (2003). Marinomonas primoryensis sp. nov., a novel psychrophile isolated from coastal sea-ice in the Sea of Japan. Int J Syst Evol Microbiol 53, 829-832.

Rosselló-Mora, R. \& Amann, R. (2001). The species concept for prokaryotes. FEMS Microbiol Rev 25, 39-67.

Smibert, R. M. \& Krieg, N. R. (1994). Phenotypic characterization. In Methods for General and Molecular Bacteriology, pp. 607-654. Edited by P. Gerhardt, R. G. E. Murray, W. A. Wood \& N. R. Krieg. Washington, DC: American Society for Microbiology.

Solano, F. \& Sanchez-Amat, A. (1999). Studies on the phylogenetic relationships of melanogenic marine bacteria: proposal of Marinomonas mediterranea sp. nov. Int J Syst Bacteriol 49, 1241-1246.

Solano, F., Garcia, E., Perez de Egea, E. \& Sanchez-Amat, A. (1997). Isolation and characterization of strain MMB-1, a novel melanogenic marine bacterium. Appl Environ Microbiol 63, 3499-3506.

Stackebrandt, E. \& Goebel, B. M. (1994). Taxonomic note: a place for DNA-DNA reassociation and 16S rRNA sequence analysis in the present species definition in bacteriology. Int J Syst Bacteriol 44, 846-849.

van Landschoot, A. \& De Ley, J. (1983). Intra- and intergeneric similarities of the rRNA cistrons of Alteromonas, Marinomonas (gen. nov.) and some other Gram-negative bacteria. J Gen Microbiol 129, 3057-3074.

van Landschoot, A. \& De Ley, J. (1984). Marinomonas gen. nov., Marinomonas communis comb. nov. and Marinomonas vaga comb. nov. In Validation of the Publication of New Names and New Combinations Previously Effectively Published Outside the IJSB, List no. 13. Int J Syst Bacteriol 34, 91-92.

Vaskovsky, V. E. \& Terekhova, T. A. (1979). HPTLC of phospholipid mixtures containing phosphatidylglycerol. J High Resolut Chromatogr Chromatogr Commun 2, 671-672.

Vaskovsky, V. E., Kostetsky, E. Y. \& Vasendin, I. M. (1975). A universal reagent for phospholipid analysis. J Chromatogr 114, 129-141.

Wayne, L. G., Brenner, D. J., Colwell, R. R. \& 9 other authors (1987). International Committee on Systematic Bacteriology. Report of the ad hoc committee on reconciliation of approaches to bacterial systematics. Int J Syst Bacteriol 37, 463-464. 